\title{
"EU ACREDITO NA VÍTIMA" E O PRINCÍPIO DA PRESUNÇÃO DE INOCÊNCIA: RELAÇÕES DE PODER E OS DIREITOS FUNDAMENTAIS NO JUDICIÁRIO BRASILEIRO
}

\section{“I BELIEVE IN THE VICTIM" AND THE PRINCIPLE OF THE PRESUMPTION OF INNOCENCE: RELATIONS OF POWER AND FUNDAMENTAL RIGHTS IN BRAZILIAN JUDICIARY}

\begin{abstract}
RESUMO: O presente artigo examina - através de uma análise bibliográfica - o movimento que possui como objetivo validar relatos das vítimas de estupro, acreditando em suas versões do caso, sua relação com o princípio da presunção de inocência e com o populismo penal midiático - o qual está associado a um debate acerca dos limites do princípio da liberdade de expressão frente à presunção de inocência. Ademais, aborda o papel fundamental das relações de poder nessa discussão, com destaque para as relações de gênero. A partir de uma análise do conceito de estupro, de como ele é tratado pelo sistema penal e do modo no qual a vítima é vista pela sociedade e, consequentemente, pelo judiciário, da importância da presunção de inocência e da cobertura midiática do crime, busca analisar se esse movimento vai realmente de encontro com o princípio da presunção de inocência.
\end{abstract}

PALAVRA-CHAVES: Estupro. Princípio da Presunção de Inocência. Populismo Penal Midiático. Vítima.

ABSTRACT: This article examines - through a bibliographic analysis - the movement that aims to validate the victims' reports in cases of rape, believing in their versions of the case, their relation with the principle of the presumption of innocence and with penal populism - which is associated with a debate about the limits of the principle of freedom of expression in the face of the presumption of innocence. Furthermore, it addresses the fundamental role of power relations in this discussion, with emphasis on gender relations. Based on an analysis of the concept of rape, how it is treated by the penal system and the way in which the victim is seen by society and, consequently, by the judiciary, the importance of the presumption of innocence and the media coverage of crime, seeks to analyze whether this movement really meets the principle of the presumption of innocence.

KEY-WORDS: Rape. Presumption of Innocence. Penal Populism. Victim.

\footnotetext{
* Graduanda do curso de Direito da Universidade do Estado da Bahia (UNEB). Integrante do curso grupo de pesquisa em Direito e Sexualdiade da Univerdade Federal da Bahia (UFBA) e do grupo de pesquisa em Direito Civil-Constitucional da UNEB/Campus I.
} 


\section{INTRODUÇÃO}

A sociedade é marcada pela presença de relações de poder decorrentes de um processo sócio histórico, isto é, caracteriza-se pela presença de relações nas quais um indivíduo (ou um grupo) está em uma posição hierarquicamente superior em comparação a outro indivíduo (ou outro grupo), possuindo, desse modo, uma série de privilégios. Uma dessas relações é a que se estabelece entre os homens e as mulheres, na qual o homem ocupa uma posição superior pelo simples fato de ser homem, o que condiz com outro traço característico da sociedade, o patriarcado, sistema no qual o homem detém o poder, ocupando posições superiores em detrimento à mulher..Esse sistema se manifesta em diferentes esferas, na social, política, familiar, trazendo múltiplas consequências negativas, as quais afetam, principalmente, as mulheres.

O modo como casos de estupros é tratado tanto pelo sistema quanto pela mídia/sociedade exemplificam as consequências negativas à mulher. Nesses casos, as vítimas (mulheres) são culpabilizadas pelos crimes que sofreram, são desacreditadas, vistas como mentirosas, e em decorrência disso, muitas escolhem não denunciar seus abusadores, especialmente quando eles são indivíduos cisgêneros héteros brancos com um significativo poder econômico.

Assim, visando mudar essa realidade, surgem movimentos em prol das vítimas, mostrando a validade de seus relatos e a importância de se acreditar em seus depoimentos, destacando a necessidade de aceitar as alegações acerca de abusos sexuais e casos de estupros como verdadeiras. É possível, todavia, considerar que esses movimentos vão de encontro a direitos fundamentais, como, por exemplo, o princípio da presunção da inocência, presente no artigo $5^{\circ}$, inciso LVII da Constituição Federal de 1988 (CF/88).

Outrossim, esses movimentos também objetivam uma alteração em relação a cobertura midiática dos casos de estupro, afirmando ser necessário mudar o foco das reportagens; em vez de dissecar a vida da vítima, começar a analisar aquele que cometeu $\mathrm{O}$ ato ilícito, o estuprador. Isso, similarmente, também pode ir contra o princípio da presunção da inocência, além de se inserir em outra discussão - o 
populismo penal midiático -, a qual engloba o conflito entre esse princípio e o da liberdade de expressão.

Diante do exposto, a proposta deste artigo é discutir como as relações de poder influenciam a percepção acerca dos casos de estupros e das vítimas e como os esforços para mudar essa visão podem ir de encontro aos direitos fundamentais. Para isso, incialmente, será analisado o que é considerado estupro - de acordo com a legislação brasileira - e como ele ocorre atualmente e é visto pela sociedade, além de discorrer acerca das mobilizações que objetivam mudar essa realidade e sobre o princípio presente no art. 5ํ, LVII da CF/88. Também será examinado o populismo penal midiático e se ele atinge a todas as parcelas da sociedade.

\section{ACREDITAR}

Brownmiller (apud Coulouris, 2010, p. 6) afirma que, para uma mulher, a definição de estupro é simples, é um ato degradante e hostil, é a invasão sexual - a qual pode ocorrer de diversos modos - de seu corpo pela força, é uma incursão em seu espaço privado sem o seu consenso, é uma violação de sua integridade emocional, física e racional. O Código Penal brasileiro, todavia, fornece uma definição mais objetiva, em seu artigo 213, define o ato como: "constranger alguém, mediante violência ou grave ameaça, a ter conjunção carnal ou praticar ou permitir que com ele se pratique outro ato libidinoso" (BRASIL, 1940).

A partir desse conceito legal, é necessário - para que determinadas condutas sejam classificadas como estupro - que o agente tenha forçado, coagido, subjugado a vítima (constranger), através do emprego de violência ou grave ameaça (que pode ser direta, indireta, implícita ou explícita), com o intuito de realizar com sucesso um ato libidinoso (GRECO, 2017, p. 90-91). Logo, o estupro, sumariamente, é um ato de natureza sexual que é realizado sem o consentimento da vítima.

A lei 12.015/2009 alterou o que constitui estupro, o unificando com o atentado de violência ao pudor e criando a ideia do delito adotada hoje. Não é mais 
indispensável que ocorra a penetração do pênis na vagina ${ }^{1}$, sendo assim, qualquer outro tipo de ato sexual também pode configurar estupro (GONÇALVES, 2018, p. 590). Logo. é dispensável que tenha ocorrido um contato físico entre o autor e vítima ou que ela seja despida para que ocorra o estupro nos termos da lei. O envolvimento do corpo da vítima em um ato sexual com um terceiro, por exemplo, também é considerado estupro. E é importante observar que o direito brasileiro admite a possibilidade de tentativa de estupro, de coautoria e de participação (GONÇALVES, 2018, p. 592(NOBRE; PEIXOTO, 2015, p. 231).

Como pode ser um ato praticado por qualquer indivíduo, o estupro é considerado um crime comum (GONÇALVES, 2018, p. 592). Logo, o fato da vítima e do agente já terem um relacionamento, seja ele amoroso, sexual ou não-sexual, não impede a ocorrência do ato ilícito. Rogério Greco afirma que mesmo que a vítima tenha indicado anteriormente o desejo da realização de um ato de natureza sexual com o agente ou tenha realizado com ele outros atos, ela ainda tem o direito de dizer o "não", de não consentir, e de ter a sua vontade respeitada. O mesmo autor, todavia, considera que em uma hipótese na qual a vítima disse "não", mas que o autor considerou o não como uma parte do "jogo da sedução", constituí um erro de tipo e, dessa forma, não configura estupro (GRECO, 2017, p. 117-118).-593). Desse modo, a visão do estupro ultrapassa a ideia de que só pode ser cometido por homem contra mulher, admitindo a possibilidade de ser praticado por qualquer indivíduo contra qualquer outro (GRECO, 2017, p. 90). É importante frisar, contudo, que a hipótese estupro cometido por homem contra mulher é a mais frequente. Segundo uma pesquisa realizada pelo IPEA (Instituto Econômico de Pesquisa Aplicada) quase 90\% das vítimas de estupro são mulheres

Vale ressaltar que o estupro é um crime doloso, ou seja, é necessário que tenha a presença do dolo na ação (agente tenha a intenção de praticar o ato) para que seja configurado o tipo penal (GONÇALVES, 2018, p. 593). Em relação a isso, Victor Gonçalves (2018, p. 594) e Greco (2017, p. 100) consideram que é dispensável que

\footnotetext{
${ }^{1}$ A partir dessa alteração, Greco considera que a vítima pode ter um papel ativo ou passivo. O primeiro refere-se a condutas nas quais o agente força a vítima a praticar um ato que não seja uma conjunção carnal, já a segunda é quando isso é praticado na vítima. O autor também considera que há hipóteses nas quais a vítima pode possuir ambos os papéis simultaneamente (GRECO, 2017, p. 95).
} 
o indivíduo tenha o intuito de satisfazer a sua libido, sendo possível casos em que ele possua outras motivações, como, por exemplo, humilhar a vítima, vingança, entre outras possibilidades.

Além disso, o estupro - semelhante aos outros tipos penais - visa proteger os bens jurídicos dos cidadãos, isto é, elementos considerados importantes para o desenvolvimento e manutenção do indivíduo e da coletividade (TONTINI, 2018). Esse tipo penal, em específico, objetiva a proteção da liberdade sexual dos indivíduos, a qual é definida como a autonomia da pessoa sobre o próprio corpo e sobre o modo, o momento ou o sujeito com quem mantém relações sexuais. Greco (2017, p. 97-98) considera que, ao atingir a liberdade sexualmente, o estupro, concomitantemente, agride a dignidade sexual da pessoa, que é humilhada pelo ato ilícito.

Essa proteção é dificultada por uma série de fatores, sendo o principal deles o fato de o estupro ser cometido, geralmente, sem a presença de testemunhas e sem provas materiais (COULOURIS, 2010, p. 20). Os exames de corpo de delito - que visam comprovar que houve um ato sexual e lesões físicas ocasionadas pelo agressor -, por exemplo, na maioria das vezes nada comprova (COULOURIS, 2010, p.18). A inutilidade da perícia está ligada a fatores, como, o fato da maior parcela das vítimas registrar a violência após o período necessário para o exame (quarenta e oito horas) ou das vítimas reagirem "automaticamente ao estupro procurando apagar da memória, através de um ritual de limpeza e expurgação, qualquer contato com o agressor logo após a violação"2 (COULOURIS, 2010, p.18). E, quando se consegue comprovar que o ato sexual realmente aconteceu, ainda é preciso provar que não houve o consentimento da vítima e que ocorreu o uso da violência física ou grave ameaça (COULOURIS, 2010, p.17). Diante disso, muitos casos de estupros ficam restritos ao depoimento da vítima contra o do seu agressor, mesmo em situações em que ocorreu uma prisão em flagrante do acusado ou em casos que ele não é um conhecido da vítima (COULOURIS, 2010, p.24).

\footnotetext{
${ }^{2}$ Coulouris (2010, p.18) aponta outros elementos relacionados ao exame de corpo de delito. Segundo ela, os resultados da perícia não costumam ser concludente porque as marcas de agressões físicas não são relacionadas, pelos peritos e agentes jurídicos, ao indício de violência sexual.
} 
Por conta disso, a doutrina compreende que se deve conferir um valor de prova aos relatos da vítima com o objetivo de evitar que ocorra uma frequente absolvição dos agentes, fornecendo, desse modo, um benefício à vítima (COULOURIS, 2010, p.25). Essa valoração faz com que, caso não haja provas mais consistentes, o depoimento da vítima pode ser considerado suficiente para sustentar a condenação do réu. Acerca disso, Gonçalves considera que o depoimento da vítima possui uma importância especial já "que esse crime normalmente é cometido às escondidas" (GONÇALVES, 2018, p. 592). Esse depoimento, entretanto, não é considerado como prova em todos os casos. Segundo Gonçalves, para possuir esse status, é necessário que ele seja prestado com convicção e de um modo coerente. Além disso, ele afirma que o juiz possui um papel fundamental ${ }^{3}$, uma vez que ele deve examinar o relato da vítima, verificando se há contradições com depoimentos anteriores, e se há uma motivação para ela tentar prejudicar o acusado, visando evitar condenações injustas (GONÇALVES, 2018, p. 593).

A mulher, então, após ter experienciado um acontecimento traumático(s) (ou uma série deles), deve prestar diversos depoimentos, que serão fortemente questionados ao longo do processo e que não podem apresentar divergências, uma vez que isso pode levar a novas dúvidas se o que ela está relatando é verídico ou não, e, normalmente, não há outras provas que corroboram com sua versão dos fatos. Em relação a isso, a socióloga Daniella Coulouris considera que há um grau de perversidade no sistema penal, uma vez que, há uma cobrança de coerência absoluta do relato da vítima, qualquer contradição pode ser entendida como uma evidência da inveracidade do depoimento. Ela aponta como um dos principais motivos - nos casos que se baseiam nesses relatos - utilizados para justificar a absolvição dos acusados é a falta de "coerência" no discurso das vítimas (COULOURIS, 2010, p. 42).

Outrossim, há uma análise excruciante, no processo de estupro, da vida da vítima, de suas ações e seus comportamentos, na tentativa de desacreditar seu relato

\footnotetext{
${ }^{3}$ É necessário considerar que, nesses processos, o juiz possui uma grande autonomia, uma vez que ele utiliza como fundamentação para suas decisões uma legislação ampla e diversas jurisprudências que são contraditórias. Há jurisprudências, por exemplo, que consideram que os exames de corpo de delito podem ser desconsiderados, mas outras consideram essenciais; há as que consideram que o depoimento da vítima é suficiente para que ocorra a condenação, outras, todavia, consideram que são necessários outros elementos para basear a sentença (COULOURIS, 2010, p. 26).
} 
e/ou justificar o estupro. De acordo com Coulouris (2010, p. 42), o "espaço indeterminado entre a queixa da vítima e a palavra do acusado" é preenchido por uma alteração no foco, não se analisa se ocorreu o crime ou não, mas sim ocorre uma investigação do comportamento social da vítima e do agente. Ou seja, diante da falta de credibilidade do discurso da mulher, busca encontrar a verdade dos fatos a partir da análise das atitudes daquela que sofreu o ato ilícito e de quem o praticou.

Essa mudança no foco possui um papel significativo no depoimento das vítimas. Em análises realizadas de processos de estupros, foi constatado que quando as vítimas detalham os acontecimentos e/ou ao responderem questionamentos acerca deles, omitem informações sobre sua conduta pessoal que poderiam lesar sua credibilidade (COULOURIS, 2010, p. 44-45). Também, quando há a prestação de seus depoimentos ocorre uma construção da verdade, isto é, o relato da vítima - que narra uma realidade complexa - é simplificado em uma linguagem formal que visa convencer a veracidade dos fatos.

Portanto, baseando-se em classificações da situação e das pessoas envolvidas nela, de uma interpretação dos acontecimentos, ocorre uma transformação que possui o intuito de fazer com que ocorra a criação de uma narração que se enquadre nos moldes de argumentação da defesa e da acusação. "Os operadores da defesa vão definir o crime e o criminoso, de acordo com sua visão do crime". Além disso, as questões formuladas - que irão fornecer os elementos que serão utilizados pela defesa e pela acusação - influenciam na facilidade das vítimas manterem a coerência de seus relatos e pode ocorrer uma ênfase no comportamento social da vítima, o que será levado em conta pelo juiz no momento de sentenciar (COULOURIS, 2010, p. 4648).

A mudança de foco também afetará a postura dos advogados e dos promotores, são construídos perfis da vítima e do agente, e narrativas que devem se encaixar neles, semelhantes aquelas que influenciam outros momentos da investigação criminal e/ou do processo penal. Dessa forma, a defesa utilizará como estratégia provar que seus clientes possuem características que demonstrem que são inocentes (isto é, não possuem antecedentes criminais, são casados, trabalhadores, pais de famílias, estudantes), enquanto, simultaneamente, tentam desacreditar o 
relato da vítima, argumentando que esta acusação está relacionada a "trama de vingança pessoal, de chantagem financeira" ou que os agentes são "vítimas de uma prostituta"4 . Já a promotoria tentará demonstrar que a vítima é uma pessoa correta, trabalhadora, ingênua ${ }^{5}$ e o réu um indivíduo violento, marginal, alcoólatra (COULOURIS, 2010, p. 19).

Então, conclui-se que o comportamento social da mulher é utilizado como uma ferramenta para desacreditar o seu relato e/ou justificar o estupro. Ela é descrita como não confiável, seja por base em doenças mentais ou por ser jovem e propensa a fantasiar. Ela será retratada como uma pessoa promíscua, que se relaciona com diferentes homens, utiliza roupas curtas, e por conta disso, foi estuprada ou consentiu o ato. Afirmarão que ela realizou a denúncia por motivos que não são a busca por justiça - como, por exemplo, vingança, não gostar do indivíduo, entre outros - o que será agravado caso o réu seja um conhecido da vítima.

Coulouris (2010, p. 19) afirma que essa desconfiança em relação à vítima origina-se de um processo sócio-histórico que está associado à representação das mulheres. A socióloga explana que há um entendimento compartilhado pela doutrina, jurisprudência e pelos juízes que a vítima consentiu a relação e há uma "desconfiança sempre suposta, de que a denúncia da vítima pode ter sido elaborada com o objetivo de prejudicar propositalmente o acusado", o que demonstra que o julgamento de estupro é desfavorável à vítima já que ela possui o dever de provar que não houve o consentimento (COULOURIS, 2010, p. 20).

A partir desse entendimento, apontado por Coulouris, de que essa desconfiança é fruto de um processo social, conclui-se que ela não está restrita à esfera judicial, estando presente em todas as esferas da sociedade. Ela, na verdade,

\footnotetext{
${ }^{4}$ Nos casos de estupro, caso seja comprovado que esse ato ocorreu, o réu não será absolvido ou legitimado, dessa forma, a defesa busca sempre negar que o fato aconteceu ou alega que havia o consentimento da vítima (COULOURIS, 2010, p. 67).

${ }^{5}$ Esse ponto de vista acerca das características da vítima de estupro está relacionado a ideia de "mulher para casar" versus "mulher desviada" (SOUSA, 2017, p. 14), dicotomia que remete, respectivamente ideia bíblica de Maria e Eva (LIMA, 2017, p. 9). A classificação que constitui a ideia de vítima de estupro seria a mulher para casar, isto é, aquela que é mais casta, virginal, caso contrário esse crime constitui um fruto do comportamento inadequado da vítima. Essas classificações acerca da mulher estão ligadas às classes sociais e raciais, a mulher negra, por exemplo, é, geralmente, vista como desviada, tendo o seu corpo hipersexualizado pela sociedade (SOUSA, 2017, p. 14-17).
} 
origina-se na sociedade e, consequentemente, possui reflexos no sistema penal. Essa visão é trazida por Adler ao afirmar que o julgamento do comportamento da vítima ultrapassou a sociedade e adentrou ao judiciário (HEBERLE; OSTERMANN; FIGUEIREDO, 2016, apud SOUSA, 2017, p. 23).

Há, desse modo, uma tentativa em conjunto de demonstrar que o relato da vítima é inverídico. Logo após o público tomar conhecimento da denúncia realizada pela vítima, por exemplo, inicia-se uma análise de sua vida e de seus comportamentos, a qual é catalisada pelas redes sociais e pela mídia. Não é um acontecimento incomum observar as pessoas analisando as fotos postadas nas redes sociais da mulher, se tinha um conteúdo considerado provocativo, seus relacionamentos passados, sua profissão, seus hábitos.

Outrossim, a sociedade é, inegavelmente, marcada por uma cultura do estupro, isto é, há a presença de uma série de elementos que auxiliam a legitimação e justificativa do estupro. Esses elementos, na maioria das vezes, são corriqueiros, sutis, implícitos e naturalizados, constituído, desse modo, uma cultura (SOUSA, 2017, p. 10). Os homens, portanto, nascem, crescem e se desenvolvem em uma sociedade na qual há discursos altamente misóginos que são a eles transmitidos de diversos modos e contribuem, fortemente, para a criação/perpetuação da ideia de que eles possuem a liberdade para estuprar a mulher, que eles têm um poder em relação ao corpo dela (SOUSA, 2017, p. 12-13).

Dessa forma, torna-se claro que essa cultura está fortemente relacionada às relações de poder que estão enraizadas na sociedade. O homem - aquele que detém o poder - possui, em seu imaginário, a ideia de que ele possui a liberdade, o poder sexual em relação ao grupo que está em uma posição hierarquicamente inferior na relação. E, na tentativa da manutenção desse poder são criados mecanismos, os quais estão tão enraizados na sociedade que muitas vezes são passados despercebidos. A cultura do estupro, então, está relacionada com a culpabilização da vítima, a relativização do estupro, a desconsideração do "não", entre outros diversos aspectos que dificultam a condenação do estuprador.

Além disso, esse privilégio, o qual o homem acredita ter em relação ao corpo da mulher, influenciará na sua visão acerca do consentimento da vítima. Ele - através 
dos mais diversos processos - aprendeu que deve aproveitar toda a oportunidade de ter uma relação sexual e que a mulher foi ensinada à não dizer o "sim" inicialmente, cabendo ao homem, através de um estímulo, fazer com que o "não" se torne um "sim" (SOUSA, 2017, p.13-21).

Ademais, essa visão da sociedade acerca do estupro e de suas vítimas ${ }^{6}$, de acordo com Greco, contribui para que a mulher "não comunique o fato à autoridade policial, fazendo parte, assim, daquilo que se denomina cifra negra" (GRECO, 2017, p. 94). Sousa (2017, p. 16-22) possui um ponto de vista semelhante, ela considera que a sociedade impõe uma visão de vítima - baseada no comportamento e reputação da mulher - quase inalcançável, além de criar a ideia de que o estupro é um acontecimento raro, que ocorre, pouquíssimas vezes, em uma rua deserta na calada da noite. Essa visão estereotipada, como já foi mencionado, não se restringe apenas à vítima; o estuprador é visto como um indivíduo de mal caráter, que tem comportamentos agressivos, doentios, fazendo com que seja difícil para a vítima enxergar uma pessoa, a qual considerava uma boa pessoa e tinha respeito, como o agente desse crime ${ }^{7}$. A partir disso, as mulheres vão compartilhar essa visão do que constitui estupro, estuprador e vítima, não considerando que tenham sofrido esse crime e, consequentemente, não realizarão a queixa. Por outro lado, quando a vítima realiza sua queixa, acaba sofrendo pressões da sociedade para que a retire. A acusação que um indivíduo cometeu o estupro é considerada como um aspecto que pode destruir a sua vida, ele passa a ser visto como uma vítima da denúncia da mulher (SOUSA, 2017, p. 15). A vítima, então, a vilã da situação, deve retirar a sua queixa para que a vida do estuprador não seja arruinada.

6 Lia Machado (apud COULOURIS, 2010, p. 71-72), em uma pesquisa realizada com detentos condenados por estupro, observou que existem três percepções acerca desse ato, duas o veem como um crime (uma de honra e a outa hediondo), enquanto a última, como um elemento presente no cotidiano do homem e da mulher, não constituindo, portanto, um ato ilícito. Vale destacar que essa visão que o caracteriza como um crime hediondo está relacionada com "as representações do ato de imposição sexual feito às mulheres que são pensadas como se fossem, ou pudessem ser, suas mães, irmãs, filhas ou irmãs; mães e filhas de outros homens que merecem consideração" (COULOURIS, 2010, p. 36). Ou seja, ele só entende esse crime em suas verdadeiras cores quando a vítima possui uma ligação a outro homem. O valor da mulher, dessa forma, está atribuído a um homem, ela não possui importância até que esteja ligada a um homem.

${ }^{7}$ A pesquisa realizada pelo IPEA demonstrou que, em 32,2\% dos casos, o estuprador é amigo ou conhecido da família, em 12,3\%, padrasto e, em 11,8\%, o pai da vítima (SOUSA, 2017, p. 19). 
Essa cifra negra nos casos de estupro é demonstrada pela pesquisa realizada pelo IPEA, a qual aponta que ocorrem no mínimo cerca de 527 mil casos anualmente no Brasil, mas apenas $10 \%$ são registrados perante as autoridades policiais. E, apesar de existir delegacias especializadas no atendimento à mulher, segundo um levantamento realizado pelo IBGE (Instituto Brasileiro de Geografia e Estatística) em 2013, apenas " $21,7 \%$ das cidades ofertavam (...) serviços especializados, como delegacias e juizados. A oferta desses serviços era maior em cidades com mais de 500 mil habitantes (85\%) e muito baixa nas cidades com até 10 mil habitantes - menos que 10\%." (FIUZA, 2016).

Assim, o homem, criado com o pensamento que deve ser o "pegador" (SOUSA, 2017, p. 14), entende que ele é superior à mulher, possuindo liberdade e poder em relação ao corpo dela. Essa ideia é corroborada, em seu imaginário, pela dificuldade de ocorrer uma condenação nos casos de estupro, o qual está relacionado ao sistema que possui diversas ferramentas para a manutenção desse privilégio dos homens. $E$ a mulher, criada com a ideia de que o seu valor moral está relacionado a sua vida sexual ${ }^{8}$ (SOUSA, 2017, p. 14), cresce internalizando vários comportamentos errados e os considerando normais ${ }^{9}$. Isso faz com que diversas vítimas não denunciem os estupros que sofreram ou continuam a sofrer, o que confirma a ideia no homem que seu ato não possui o status de ilícito. Fica, então, perceptível que se trata de um complexo sistema - baseado nas relações de poder - no qual um elemento contribui para a existência de outro e vice-versa.

Diante dessa realidade, surgem movimentos, principalmente nas redes sociais, que visam dar credibilidade ao relato das mulheres que são desacreditadas pela sociedade. Esses movimentos demonstram à mulher que existem pessoas que acreditam em seu depoimento, criticam a mídia por apontar apenas a vítima e não o acusado nas reportagens e auxiliam na busca pela justiça. Um claro exemplo desses

8 O Instituto Avon em conjunto com a Data Popular, em 2014, realizou uma pesquisa com 2.046 indivíduos com idades entre 16 e 24 anos, demonstrou que $68 \%$ acham errado a mulher ir para a cama no primeiro encontro e $76 \%$ criticam aquelas que têm vários "ficantes" (POLATO; ALVES. 2014).

9 De acordo com a pesquisa do Instituto Avon e da Data Popular, em relacionamentos é comum a presença de ações de controle e violência contra as mulheres, uma vez que, $53 \%$ delas afirmam que já tiveram o celular vasculhado, $40 \%$ que o parceiro controla o que fazem, onde e com quem estão, $35 \%$ que foram xingadas pelo namorado e $33 \%$ que o parceiro as impediram de usar uma certa roupa (POLATO; ALVES. 2014). 
movimentos é o I Believe Her ou Believe women (respectivamente "eu acredito nela" e "acreditem nas mulheres"), o qual possui o intuito de demonstrar que as mulheres são ouvidas, que a suas alegações são levadas a sérios e, portanto, serão investigadas (HESSE, 2020).

Todavia, alguns consideram que tais ações podem ir de encontro com um dos direitos fundamentais, o princípio da presunção de inocência, uma vez que argumentam que ao acreditar na mulher, concomitantemente, estaria considerando o réu como culpado sem que tenha passado pelos trâmites legais. Ademais, é possível considerar que a mídia, ao apontar o acusado, adentraria ao populismo penal midiático.

Assim sendo, torna-se evidente que variados fatores corroboram para que 0 estuprador não seja condenado; a desconfiança em relação ao relato da mulher, os estereótipos acerca do estupro, do estuprador e da vítima e as críticas aos movimentos de apoio às vítimas são alguns deles. Esses fatores surgem - através de um processo de construção -, em uma sociedade marcada por relações de poder, como uma ferramenta para a manutenção do privilégio que o homem acredita possuir em relação ao corpo da mulher.

\section{INOCÊNCIA}

O princípio da presunção de inocência está previsto no art. 5ㅜ, LVII da CF/88, o qual considera que: "ninguém será considerado culpado até o trânsito em julgado de sentença penal condenatória" (BRASIL, 1988), isto é, apenas após o processo ser concluído - a sentença não caber mais recurso -, o réu poderá ser considerado culpado e, consequentemente, cumprirá uma penalidade. Além da Constituição, ela também está prevista na Declaração Universal dos Direitos Humanos, no artigo 1ํㅡ, (TURA, 2016, p. 11) e no Código Penal para a América Latina (TURA, 2016, p. 13).

Essa presunção já era garantida na França, em um cenário pós-Revolução Francesa, na Declaração do Direito do Homem e do Cidadão em 1786 (TURA, 2016, p. 10), sendo que a origem desse princípio está relacionada ao movimento iluminista e a pensadores como Montesquieu, Voltaire e Beccaria (TURA, 2016, p. 10). 
Anteriormente, nos Regimes Absolutistas, o modo que o processo penal transitava era muito divergente ao atual, o magistrado, por exemplo, possuía funções de instrução, acusação e julgamento e, ao réu, não era garantido o direito à resposta. $A$ tortura era amplamente utilizada, não havia a ideia de proporcionalidade da pena e, geralmente, os presos eram considerados indivíduos "perigosos, ou com ideias muito revolucionárias ao sistema da época, lhe eram imputados supostos crimes, nos quais eles pagavam pelos restos de suas vidas, ou até mesmo com suas vidas, sem lhes dar nem um direito de resposta e defesa" (BAPTISTA, 2014, p.14-15). O réu, portanto, era visto como culpado, cabia a ele o dever de comprovar sua inocência. Todavia, como já mencionado -, muitas vezes, ele não possuía o direito de se defender das acusações. Visando garantir ao cidadão o direito a um julgamento justo, além de fornecer à sociedade uma espécie de senso de segurança, surge o direito ao contraditório, a ampla defesa e o princípio da presunção da inocência, os quais são implementados gradativamente no Direito Penal.

Logo, o princípio da presunção de inocência é um dos direitos fundamentais garantidos ao cidadão brasileiro. Esses direitos - os quais o Estado possui o dever de garantir - são diversas normas presentes na CF/88, que são vistas como essenciais à uma vida digna e que garantem as condições mínimas de vida e desenvolvimento do ser humano (TURA, 2011, p. 11).

Fica evidente, desse modo, a importância desse princípio para o ordenamento jurídico brasileiro. É ele que garante ao réu os meios legais que oportunizam a sua defesa, que permitem que ocorra um verdadeiro esforço para encontrar os verdadeiros autores do ato ilícito, que possibilita que um indivíduo não seja considerado culpado antes de uma análise cuidadosa das provas produzidas. É possível considerar que ir de encontro com esse princípio significa uma afronta a um processo penal justo.

Além disso, o Estado é detentor absoluto do jus puniendi, isto é, o direito de punir; apenas ele possui a habilidade de deliberar acerca de um conflito criminal, de um modo institucional, racional, formal, e obedecendo as garantias presentes na jurisdição. Ao impor a pena, o Estado está limitando o jus liberatis do indivíduo, isto é, o direito à liberdade, a qual pode ser considerada um dos bens jurídicos mais 
importantes do cidadão. Desse modo, cabe a ele, ao considerar alguém culpado, ter certeza absoluta de sua decisão (TURA, 2011, p.11).

Por conseguinte, no caso em que há dúvidas acerca da culpabilidade do réu, ele deve ser considerado inocente, trata-se do princípio da dubio pro reo (na dúvida, a favor do réu) (TURA, 2011, p. 16). Deve, então, "a parte acusadora (...) ter provas que possam comprovar a culpabilidade do réu, de forma que não haja dúvida da culpa, caso contrário não poderá ser transitado sentença de incriminação por parte do juiz (TURA, 2011, p. 16).

Analisando a relação do princípio da presunção de inocência com os processos de estupro, de acordo com Coulouris (2010, p.55), a presunção da inocência e as dúvidas em relação ao relato da vítima contribuem para o andamento do processo, uma vez que tendo como base a ideia que o acusado é inocente ou que o ato foi consentido, é que uma investigação de verdade ocorre. A socióloga ressalta que cabe à vítima comprovar que o estupro realmente ocorreu.

Assim, é compreensível o ultraje em uma simples fala "eu acredito na vítima" quando os devidos trâmites legais não aconteceram ainda. Todavia, essa fala visa a ocorrência da desconsideração por completo desse princípio ou uma alteração no modo em que a vítima e o seu relato são vistos pela sociedade e, consequentemente, pelo sistema?

Vale destacar que, em relação ao estupro, a mulher é considerada vítima não de acordo com os acontecimentos envolvendo o ato ilícito, mas sim através de uma análise de sua reputação (SOUSA, 2017, p. 16). A vítima tem sua vida e comportamentos julgados, além de ser, constantemente, questionada acerca da veracidade de seu relato e dos motivos para realizar a queixa. Essa vítima, logo, não será julgada apenas pelo judiciário, mas sim, por todo o sistema penal e pela sociedade. Esses aspectos os quais incidem em relação à vítima estão, inegavelmente, relacionados às relações de poder, uma vez que constituem meios para a perpetuação de uma série de privilégios que o homem possui.

É evidente a importância do princípio da presunção da inocência para que o processo penal seja justo. Os movimentos que visam apoiar os relatos da mulher não vão de encontro a ele, na realidade, eles surgem com o intuito de mudar um padrão 
cultural no qual, por conta da visão da sociedade acerca desse crime, as vítimas não realizam a queixa, não vão adiante com o processo, são julgadas, criticadas ou entendem, simplesmente, que não sofreram estupro.

\section{MÍDIA}

Os meios de comunicação possuem um enorme poder na sociedade, sendo considerados por alguns - a partir da divisão dos poderes em executivo, legislativo e judiciário - o quarto poder, já que eles têm um papel importante na politização da opinião pública e, geralmente, no controle crítico dos outros poderes (BAPTISTA, 2014, p. 40). Diante dessa importância, Ramonet (apud MELLO, 2010, p. 20) constrói uma hierarquia dos poderes e considera que a mídia constitui o segundo poder. $O$ primeiro poder, para ele, seria o econômico, e o político (o qual se desdobra nos três poderes mencionados anteriormente) seria o terceiro. A imprensa, portanto, possui duas funções fundamentais: informar a população acerca dos acontecimentos e fiscalizar o Estado, contribuindo para "esclarecer e enriquecer o debate democrático" (CAETANO, 2016, p. 21).

Todavia, os meios de comunicação vêm se afastando desses papéis, uma vez que, atualmente, a imprensa possui - como principal objetivo - lucrar. Ou seja, ela ao escolher aquilo que divulgará - não analisa a veracidade da notícia e a importância dessa informação à sociedade, mas se elas atrairão o público, fornecendo aos portais e programas jornalísticos um elevado número de leitores, espectadores, e, consequentemente, o lucro. A notícia ${ }^{10}$ passa a ser vista como uma mercadoria e, portanto, passa a se sujeitar às regras do mercado (CAETANO, 2016, p. 20-21).

Baseando-se nesse desejo de lucrar, a mídia - para atrair o público - utiliza o crime, uma vez que ele desperta um fascínio na população, e, ao mesmo tempo, provoca medo (CAETANO, 2016, p. 9), e "oferece drama, violência, ação, características que oferecem à mídia um elevado potencial noticioso e ficcional"

${ }^{10}$ É importante destacar que a mídia não se resume a visão tradicional de imprensa (jornal impresso e programas televisivos que possuem um caráter jornalístico), mas também envolve os portais de notícias e as redes sociais, os quais atualmente possuem um papel importantíssimo em relação ao compartilhamento de notícias. 
(MELLO, 2010, p. 114). A imprensa, dessa forma, constrói uma narrativa acerca do crime, ocorre uma "novelização", através de um espetáculo criado por meio de imagens e vinculadas a um enredo. Ela noticia, utilizando de discursos acusatórios, sem se basear nas investigações policiais que estão ocorrendo (ou irão acontecer) e sem se importar se o indivíduo acusado é inocente ou culpado (CAETANO, 2016, p. 9).

Além disso, a sociedade entende que a realidade é apenas composta pelos acontecimentos narrados nas reportagens apresentadas pelos meios de comunicação, uma vez que há a ideia que a mídia é onipresente, isto é, ela está sempre em todos os locais e, dessa forma, cobrirá todos os acontecimentos simultaneamente (CAETANO, 2016, p. 16-17). Esse pensamento é exacerbado pelas redes sociais e pelo imediatismo da sociedade, que espera a veiculação da notícia tão logo ocorra o crime, não se importando pela veracidade das informações ou pela conclusão das investigações.

Outrossim, Ramonet (apud CAETANO, 2016, p. 17) considera que aquilo apresentado pela mídia como verdadeiro, a sociedade enxerga como verdade, pois ela é influenciada pela imprensa, pelas informações fornecidas por diferentes meios de comunicação, que noticiam, de uma forma semelhante, os mesmos acontecimentos. Ocorre, dessa forma, uma construção da realidade, a qual - de acordo com Searle (apud CAETANO, 2016, p. 18) - se baseia em valores e costumes apresentados com a utilização da linguagem. E mesmo a situação não sendo verídica, quando as pessoas acreditam que é, as consequências dessa crença serão verdadeiras.

Diante disso, no imaginário da população, o crime constitui o novo normal e a paz uma exceção, pois a mídia constantemente bombardeia a sociedade com reportagens acerca deles. (CAETANO, 2016, p. 21). Portanto, entende-se que as leis têm que ser mais duras para garantir a segurança da população e alterar essa realidade que, ao seu ver, é marcada pela presença de atos ilícitos. Trata-se do populismo penal midiático.

Vale destacar que se entende que o papel da mídia é compartilhar informações e segundo Helena Najjar Abdo (apud BAPTISTA, 2014, p. 39), informação é o 
"conjunto de fatos ou notícias da atualidade que serão levados a conhecimento público"), ela é caracterizada pela objetividade. Lippman (apud CAETANO, 2016, p. 18), todavia, afirma que a notícia não representa a realidade, mas sim uma versão dela, uma vez que o jornalista a apresenta "mediante as suas lentes, emprestando ao enunciado, ainda de forma inconsciente, seus próprios valores e estereótipos" (CAETANO, 2016, p. 18). Além disso, há a tendência da mídia de ser opinativa explicitamente em relação ao que noticia, o que acaba influenciando as pessoas, geralmente sem que elas percebam.

Assim, quando noticia um crime, os meios de comunicação consideram um determinado indivíduo como culpado, possibilitando que a sociedade entenda que aquela pessoa foi a responsável por aquele ato ilícito. Mello (2010, p. 107) afirma que a mídia repete incessantemente as cenas do crime, de um modo que o suspeito é considerado o autor, passando a ter sua imagem divulgada e sua vida analisada. Logo, “(...) a mídia identifica o acusado, o transforma em celebridade e chama o público para julgá-lo" (MELLO, 2010, p. 107). A sociedade, então, espera que esses indivíduos apontados como culpados sejam penalizados e, caso o judiciário for de encontro ao seu ponto de vista, compreende-se que ele não cumpriu o seu devido papel (CAETANO, 2016, p. 9).

Ao apontar um indivíduo como o culpado de um crime, a mídia possibilita que ele seja lixado pela sociedade, ameaçado, humilhado, entre outras terríveis consequências, sem possuir ilícito a certeza que foi ele quem realizou o ato. Foi isso que ocorreu, em 1994, no caso da Escola Base - uma instituição de ensino infantil da rede particular -, na qual seis pessoas ligadas à escola (proprietários e funcionários) foram acusadas de abusar sexualmente alguns alunos, os quais tinham 4 anos na época. O delegado, ao receber a queixa, a divulgou e, em pouco tempo, a mídia já estava reportando sobre o caso, geralmente, exagerando as informações que obtiveram e considerando esses indivíduos culpados, sem possuir provas para corroborar com aquilo que noticiavam. Como consequência disso, a escola teve que fechar e "as pessoas acusadas tiveram suas casas depredadas, foram ameaçadas, ofendidas, humilhadas publicamente por onde quer que passassem". Posteriormente, o caso foi arquivado (BAPTISTA, 2014, p. 54-56). Além desse, ocorreu um caso 
semelhante com Fabiane de Jesus; após uma publicação em uma rede social, na qual uma mulher com uma descrição semelhante a sua aparência foi acusada de praticar magia negra e utilizar crianças em seus rituais, Fabiane foi vítima de agressões físicas que resultaram em sua morte (BAPTISTA, 2014, p. 56-57).

Logo, fica evidente que a mídia, ao noticiar o crime, afasta-se do princípio da presunção de inocência. Ela - sem que os trâmites legais para que o indivíduo seja considerado culpado pelo judiciário tenham ocorrido - aponta, como se tivesse uma certeza absoluta, uma pessoa como a culpada por um crime. A sociedade enxerga, consequentemente, aquele indivíduo como culpado e exige que o Estado tome as providências necessárias para que ele seja penalizado, já que ele foi responsável por um crime. Desse modo, conclui-se que o modo no qual o direito à liberdade de expressão é aplicado na imprensa atualmente - sem que ocorra um controle acerca do que está sendo noticiado e do modo como é noticiado - fere o direito da presunção de inocência ${ }^{11}$.

Essa influência da mídia em relação a visão do crime e do sistema penal, no Brasil, ocorre, na grande maioria dos casos, de uma forma livre e sem quaisquer limitações, uma vez que não há legislação pertinente à matéria. Isso está relacionado com o fato da CF/88 ter sido criada no período de redemocratização do país, após a Ditadura Militar - época marcada pela censura. Dessa forma, ela garante, como direito fundamental, o direito à informação, e à liberdade de expressão (art. 5ํ, IX) e manifestação (art. 5ำ IV) - as quais compõe a liberdade de imprensa - e, afirma no art. 220 que:

A manifestação do pensamento, a criação, a expressão e a informação, sob qualquer forma, processo ou veículo não sofrerão qualquer restrição, observado o disposto nesta Constituição.

$\S 1^{\circ}$ - Nenhuma lei conterá dispositivo que possa constituir embaraço à plena liberdade de informação jornalística em qualquer veículo de

\footnotetext{
11 Apesar disso, o Código de Ética dos Jornalistas afirma, em seu nono artigo, que esse princípio constitui um "dos fundamentos da atividade jornalística" (CAETANO, 2016, p. 43.). E o artigo 14, considera que o jornalista deve "(...) ouvir sempre, antes da divulgação dos fatos, todas as pessoas objeto de acusações não comprovadas, feitas por terceiros e não suficientemente demonstradas ou verificadas (...)." Já o artigo 15 diz que caso for provado que houve equívoco ou elementos incorretos os indivíduos terão direito a resposta. (MELLO, 2010, p. 60-61).
} 
comunicação social, observado o disposto no art. 5ํㅗ IV, V, X, XIII e XIV.

$\S 2^{\circ}$ - É vedada toda e qualquer censura de natureza política, ideológica e artística.

(...)

§6ำ - A publicação de veículo impresso de comunicação independe de licença de autoridade (BRASIL, 1988).

Ademais, acerca disso, Caetano (2016, p. 28) explana que se a liberdade de informação jornalística for exercida integralmente também serão prejudicadas, além da presunção da inocência, a dignidade humana da pessoa investigada e a proteção dos direitos da personalidade daquele investigado. Nesses casos, quando há uma colisão entre dois princípios, Robert Alexy considera que um deve ceder em relação ao outro, levando em consideração o princípio da proporcionalidade. Isso, todavia, não quer dizer que um será considerado inválido, ou que deverá ser introduzida uma cláusula de exceção, mas sim que, em determinadas situações, um deverá prevalecer em relação ao outro (CAETANO, 2016, p. 28).

No judiciário brasileiro, todavia, não há um entendimento consolidado, nesses casos, sobre qual princípio deverá prevalecer, uma vez que é necessário ser analisado cada caso de acordo com suas peculiaridades. Eles, portanto, deverão ser resolvidos através de processos judiciais. Isso, todavia, não constitui a solução ideal, pois para que se tenha entrada no processo é necessário que, primeiramente, a mídia noticie que aquele indivíduo é culpado, já moldando a opinião da sociedade acerca dele.

Outrossim, nos casos de estupro, quando a vítima presta uma queixa acusando um homem de a ter estuprado ou simplesmente compartilha um relato nas redes sociais, caso a imprensa tenha conhecimento disso e noticie essa informação do modo costumaz, percebe-se que uma particularidade: quando os acusados vão de encontro com os estereótipos de criminosos que se perpetuam na sociedade, o foco da notícia passa a ser a vítima, mesmo que involuntariamente e/ou de um modo implícito.

A mídia, então, inicia uma análise minuciosa do comportamento social da vítima, "sendo ela taxada como culpada, seja por seu comportamento ou roupas, que, segundo alegam, acabam por instigar o homem e, assim, influenciam na prática do 
delito" (NOBRE; PEIXOTO, 2015, p. 323). Ou então, a ela associam uma narrativa na qual estava mentindo, buscando encontrar motivos que justifiquem a inveracidade de seu relato. A humilhação, os julgamentos, os preconceitos que, em outra situação, seriam atribuídos aos acusados, nesses casos, estão ligados à vítima.

Esse foco da notícia, nas reportagens dos crimes de estupro, está relacionado com as relações de poder. A mídia, nesse caso, é uma ferramenta fundamental na manutenção do poder, uma vez que é através dela que a realidade da população é construída, ela não é utilizada em prol da sociedade, mas sim daqueles que detêm o poder. Os homens, então, possuem um interesse na mídia noticiar a vítima, em vez do acusado, pois ela traz um discurso influenciado pelos estereótipos de vítima ideal, de justificação do crime, que a sociedade associará como verdade.

Logo, a mídia corrobora na perpetuação da cultura do estupro na sociedade, ainda que de um modo indireto. Os movimentos que consideram ser necessário que a mídia aborde o acusado nesses casos é uma tentativa de mudar essa realidade, já que a vítima não é uma pessoa que já sofreu uma violação e terá, constantemente, sua vida e relatores julgados e questionados por grandes veículos de comunicação que possuem uma enorme influência acerca da percepção da sociedade sobre os fatos.

Portanto, apesar da mídia costumeiramente, ao noticiar os crimes, concentrar no indivíduo que considera culpando antes que os tramites legais ocorram, nos casos de estupro, geralmente, se percebe o oposto. A mídia direciona o seu olhar para a vítima, trazendo o julgamento realizado pela sociedade para as reportagens e perpetuando essa visão acerca do estupro e da vítima. Assim sendo, os movimentos em prol da defesa da vítima, ao questionar esse foco da mídia, faz uma tentativa de alterar o modo em que a vítima é tratada e que, consequentemente,essa atitude influencia para que muitas mulheres não prestem queixas e/ou que os estupradores não sejam condenados. 


\section{CONCLUSÃO}

Os casos de estupro possuem uma característica fundamental: frequentemente, eles se resumem a um embate entre o depoimento da vítima e o do acusado. Tendo isso em vista, com o objetivo de evitar uma absolvição em massa, é dado, ao relato da vítima, um privilégio. Todavia, esse status traz ao depoimento uma série de exigências, uma vez que ele possui o poder de condenar um indivíduo. Espera-se que os relatos da vítima sejam absolutamente coerentes, mas deve ser lembrado que a vítima está contando, diversas vezes, um acontecimento - ao seu ver traumatizante - para um indivíduo ou um grupo que está constantemente questionando a veracidade dos fatos por ela relatados. E a transcrição desses depoimentos não é feita na íntegra do relato da vítima, pois a pessoa que está interrogando a vítima, adequa suas respostas, transcrevendo o que considera mais importante para o curso do processo.

Outrossim, diante da falta de provas e da necessidade de invalidar o relato da vítima, o processo penal nos casos de estupro é marcado pela existência de estereótipos, isto é, de uma visão pré-concebida daqueles que são considerados inocentes, dos culpados, da mulher vítima e da mulher que está relatando um fato inverídico, a partir de seus comportamentos sociais. É com base nessas visões, que a defesa e acusação constroem seus argumentos.

Todavia, torna-se de fundamental importância destacar que a desvalorização do discurso da vítima não está restrita ao judiciário, mas sim, está como resultado de uma construção sócio-histórica que visa a manutenção do poder do homem na sociedade. A sociedade é marcada pela presença de uma relação de poder entre o homem e a mulher, na qual o homem está em uma posição hierarquicamente superior e, por conta disso, detém uma série de privilégios. O homem entende que possui uma liberdade em relação ao corpo da mulher, que ele está livre para fazer o que quiser com ele sem que ocorra represálias.

A junção desses elementos faz com que um número reduzido de vítimas preste denúncias ou desistam delas, o que contribui para a perpetuação do poder dos homens. Diante disso, surgem movimentos que querem dar credibilidade a voz da 
mulher nos casos de estupros, demonstrando que existe uma rede de apoio que acredita em seus relatos. Entretanto, críticas são atribuídas a isso, uma vez que creem que fere o princípio da presunção de inocência.

Porém, acreditar na vítima não significa uma desconsideração total ao princípio da presunção de inocência, mas sim uma tentativa de mudança no modo em que ela e seu relato são vistos pela sociedade e pelo judiciário. Ademais, é fundamental que também ocorra uma alteração em relação aos estereótipos e as narrativas construídas a partir deles, uma vez que todos podem cometer o estupro ou ser vítimas dele.

Quando o acusado não se enquadra nos estereótipos que a mídia/sociedade possui acerca dos criminosos, o foco das notícias são sempre as vítimas, nesses casos, ela tem sua vida pessoal, profissional, seus comportamentos sociais reportados pela imprensa e analisados, criticados, pelos veículos de comunicação e pela sociedade, em uma tentativa de desmerecer o seu relato e/ou justificar esse ato ilícito. Então, nesses casos, ao querer que os acusados sejam apontados, é apenas um questionamento do porquê da vítima - que foi quem sofreu o ato, que não teve nenhuma escolha nesse processo - é a única a ser analisada e julgada desse modo.

O populismo penal midiático tem consequências terríveis, todavia, para alterar essa realidade é necessário que ocorra uma mudança no modo em que a mídia cobre os acontecimentos atualmente e na legislação.

As vítimas, na grande maioria dos casos, não têm motivos ocultos para denunciar um homem, elas buscam apenas a justiça, uma reparação - que na grande parcela dos casos não é suficiente - para o evento que passou. Acreditar na vítima, nesse caso, não é ferir o princípio de proteção à inocência, mas sim uma tentativa de auxílio na sua jornada em busca de um processo penal que seja justo tanto para ela quanto para o acusado.

\section{REFERÊNCIAS}

BAPTISTA, I. A Eficácia do Princípio da Presunção da Inocência Frente à Influência dos Meios de Comunicação. 2014. 64 f. Monografia (Graduação) Faculdade de Direito de Presidente Prudente, Presidente Prudente, 2014. Disponível em: 
https://d1wqtxts1xzle7.cloudfront.net/52700787/MONOGRAFIA_FRANCIELE_RENA TA_TURA_-_PDF.pdf?1492630911=\&response-content-

disposition=inline\%3B+filename\%3DINSTITUTO_DE_ENSINO_SUPERIOR_DE_GO IAS_DE.pdf\&Expires $=1606910916 \&$ Signature $=g 01 z 9 z u X N M N K t m Q q 2 n M 3 C v 3 d I 5 i O$ bVy5clYaTfTAbHkSgcZdgQiaG8t6qOKskZASkGVu gLWxkMBNRPmt3ILk10WbXrsz 01-

tj0TROzzPYvoEXnwDRuvm7 nYwuNfYatAG790BmLATI0 5z4EMwCkQbSDHPVN8 O72BqhJCNZTabjQ In3iYUW4a1PjZ6kIs5PeiOG0KphQFfnQV-

0D0TwBIYk8wqOVwP ONnbITsrdMUkni28HUritoNKwHV9HfUI097Lap36BrWd10SiZ 8zddz5cJtMrRSEibnQ6Ns AVhpO7b5eT dLBt07cylEKclZHVICVfEFYoVjyX cZ w_ \&Key-Pair-Id=APKAJLOHF5GGSLRBV4ZA. Acesso em: 24 nov. 2020.

BRASIL. Constituição (1988). Constituição da República Federativa do Brasil. Brasília, DF: Senado, 1988.

CAETANO, F. Espetacularização do Processo Penal e as Consequências do Populismo Penal Midiático. 2016. 71 f. Dissertação (Graduação) - Pontifícia Universidade Católica do Rio Grande do Sul, Porto Alegre, 2016. p. 21. Disponível em:

https://www.academia.edu/27867841/Espetaculariza\%C3\%A7\%C3\%A3o_do_Proces so_Penal_e_as_consequ\%C3\%AAncias_do_Populismo_Penal_Midi\%C3\%Ā̄tico. Acesso em: $\overline{9}$ set. 2020.

COULOURIS, D. A Desconfiança em Relação à Palavra da Vítima e o Sentido da Punição em Processos Judiciais de Estupro. 2010. 242 f. Tese (Doutorado) -

Faculdade de Filosofia, Letras e Ciências Humanas (FFLCH), Universidade de São Paulo, São Paulo, 2010. Disponível em:

https://teses.usp.br/teses/disponiveis/8/8132/tde-20092010-155706/pt-

br.phphttps://teses.usp.br/teses/disponiveis/8/8132/tde-20092010-155706/pt-br.php.

Acesso em: 25 nov. 2020.

Decreto-Lei 2.848, de 07 de dezembro de 1940. Código Penal. Diário Oficial da União, Rio de Janeiro, 31 dez. 1940.

FIUZA, E. Proteção às vítimas ainda é insuficiente. Em Discussão: n. 27, maio 2016. Disponível em:

https://www12.senado.leg.br/emdiscussao/edicoes/saneamento-basico/violenciacontra-a-mulher/protecao-as-vitimas-ainda-e-insuficiente. Acesso em: 02 dez. 2020.

GRECO, R. Curso de Direito Penal: Parte Especial, Volume III. 14. ed. Niterói: Impetus, 2017. p. 91-92.

GONÇALVES, V. E. R. Direito Penal Esquematizado: Parte Especial. 8. ed. São Paulo: Saraiva, 2018. 
HESSE, M. 'Believe Women' was a slogan. 'Believe all women' is strawman.

Washington Post: Washington, maio 2020. Disponível em:

https://www.washingtonpost.com/lifestyle/style/believe-women-was-a-slogan-believeall-women-is-a-strawman/2020/05/11/6a3ff590-9314-11ea-9f5e-

56d8239bf9ad_story.html. Acesso em: 18 dez. 2020.

LIMA, L. L. da G.Cultura do Estupro, Representações de Gênero e Direito. Language and Law / Linguagem e Direito, v. 4, n. 2, 2017, p. 7-18. Disponível em:

http://ojs.letras.up.pt/index.php/LLLD/article/view/3280/2950. Acesso em: 17 dez. 2020.

MELLO, C. G. de. Mídia e Crime: Liberdade de Informação Jornalística e Presunção de Inocência. Revista de Direito Público, Londrina, v. 5, n. 2, p. 106-122, ago. 2010. Disponível em:

http://www.uel.br/revistas/uel/index.php/direitopub/article/view/7381. Acesso em: 24 nov. 2020.

NOBRE, B. P. R; PEIXOTO, A. F. A Responsabilização da Mulher Vítima de Estupro. Revista Transgressões: Ciências Criminais em Debate, Natal, vol. 3, n. 1, maio 2015. Disponível em: https://periodicos.ufrn.br/transgressoes/article/view/7203. Acesso em: 25 nov. 2020.

POLATO, A.; ALVES, C. 48\% dos jovens acham errado mulher sair sem 0 namorado, diz pesquisa. G1: São Paulo, dez. 2014. Disponível em:

http://g1.globo.com/bemestar/noticia/2014/12/48-dos-jovens-acham-errado-mulhersair-sem-o-namorado-diz-

pesquisa.html\#: :text=Em\%20pesquisa\%20divulgada\%20nesta\%20quarta,\%2C\%20 namorado\%20ou\%20\%22ficante\%22.\&text=Ao\%20mesmo\%20tempo\%2C\%2068\%2 5\%20dizem,que\%20t\%C3\%AAm\%20v\%C3\%A1rios\%20\%22ficantes\%22. Acesso em: 27 nov. 2020.

SOUSA, R. F. de. Cultura do Estupro: Prática e Incitação à Violêncai Sexual Contra a Mulheres. Estudos Feministas, Florianópolis, v. 25, n. 1, p. 9-29, 2017. Disponível em: https://www.scielo.br/scielo.php?pid=S0104-

026X2017000100009\&script=sci_abstract\&tIng=pt. cesso em: 17 dez. 2020.

TURA, F. A Influência da Mídia no Tribunal do Júri em Face da Presunção de Inocência. 2016. 65 f. Monografia (Graduação) - Instituto de Ensino Superior de Goiás, Formosa, 2016. Disponível em:

https://repositorio.ufpb.br/jspui/bitstream/123456789/13738/1/IRS28112018.pdf. Acesso em: 24 nov. 2020.

TONINI, C. O Que é a Espiritualização do Bem Jurídico?. JusBrasil: 2018.

Disponível em: https://canalcienciascriminais.jusbrasil.com.br/artigos/718270942/oque-e-a-espiritualizacao-do-bem-juridico. Acesso em: 17 dez. 2019. 